\title{
Gambaran Fraksi Ejeksi secara Ekokardiografi pada Anak Kurang Energi Protein di RSUP Hasan Sadikin, Bandung
}

\author{
Dedet Hidayat, Sri Endah Rahayuningsih, Armijn Firman
}

\begin{abstract}
Sejak lama diketahui bahwa Kurang Energi Protein (KEP) berat dapat menyebabkan kelainan kardiovaskular yang dapat menimbulkan kematian. Hal ini disebabkan oleh atrofi jantung selama starvasi, tetapi masih tetap diperdebatkan mengenai kapan jantung pada anak KEP mulai menunjukkan gangguan fungsi. Tujuan dari penelitian ini adalah untuk mengetahui gambaran fraksi ejeksi (FE) ventrikel kiri anak dengan berbagai derajat KEP yang berkunjung ke Instalasi Rawat Jalan serta yang dirawat di Bagian Anak Rumah Sakit Umum Pusat (RSUP) Dr. Hasan Sadikin, Bandung. Penelitian ini bersifat deskriptif dengan rancangan cross sectional dilakukan pada bulan Desember 2000 sampai Februari 2001 dengan memeriksa FE 30 anak KEP I sampai III berdasarkan klasifikasi Waterlow, menggunakan alat ekokardiografi $M$-Mode. Pada penelitian ini didapatkan bahwa nilai FE sudah mulai menurun pada 73,3\% anak KEP I, 90,9\% anak KEP II dan menurun pada seluruh anak KEP III. Kesimpulan: fraksi ejeksi sudah mulai terganggu pada sebagian besar anak KEP I.
\end{abstract}

Kata kunci: KEP-fraksi ejeksi

$C$ urang energi protein sampai saat ini masih merupakan masalah besar kesehatan masyarakat di dunia khususnya di negara yang sedang berkembang, karena masih merupakan salah satu penyebab utama kesakitan dan kematian pada anak. ${ }^{1}$ Krisis moneter yang berkepanjangan sejak pertengan tahun 1997 berdampak luas terhadap aspek kehidupan masyarakat Indonesia termaksuk aspek gizi. Menurut SUSENAS tahun 1999, sekitar juta (26,4\%) balita menderita gizi kurang $(\mathrm{BB} / \mathrm{U}<-2 \mathrm{SD})$ dan 1,7 juta $(6,3 \%)$ di antaranya menderita gizi buruk $(B B /$ $\mathrm{U}<-3 S D) .{ }^{2}$ Kurang energi protein dapat menghambat pertumbuhan anak, karena terjadi pengurangan masa otot secara menyeluruh dan atrofi berbagai organ masuk jantung; hal ini akan mempengaruhi sistem kardiovaskular, baik terhadap struktur maupun fungsinya. Kelainan kardiovaskular pada KEP berat

Alamat korespondensi:

Dr. Dedet Hidayat, Sp.A.

Bagian Ilmu Kesehatan Anak FK-UNPAD/ Rumah Sakit Dr. Hasan Sadikin Bandung. Jl. Pasteur no.38, Bandung.

Telepon: 022-2034426 Fax: 022-2035957. antara lain bradikardi, hipotensi, curah jantung berkurang, pulsasi arteri perifer yang lemah, kardiomiopati, disritmia, gagal jantung bahkan kematian mendadak. ${ }^{3,4}$

Meskipun terapi nutrisi sudah maju, angka kematian anak dengan KEP berat masih tinggi. Pada umumnya kematian disebabkan oleh dehidrasi, gangguan elektrolit, hipoglikemia dan infeksi; namun pada sebagian kecil penderita, penyebab kematian tidak selalu jelas, meskipun telah dilakukan pemeriksaan laboratorium dan patologi anatomi. ${ }^{5}$ Umumnya kematian timbul mendadak, dan terjadi pada saat anak menunjukkan perbaikan/masa pemulihan, gagal jantung dianggap sebagai penyebab kematian pada anak-anak tersebut. $^{6}$

Pada penderita KEP, terjadinya gangguan fungsi jantung disebabkan oleh karena otot jantung mengalami atrofi sebagai akibat starvasi, yang merupakan bagian dari atrofi otot secara menyeluruh. ${ }^{7}$ Umumnya para peneliti saat ini sepakat mengenai hal tersebut, tetapi masih tetap diperdebatkan mengenai kapan jantung yang mengalami atrofi masih berfungsi normal atau sudah mulai menunjukkan gangguan 
fungsi ventrikel kiri ${ }^{5,8,9}$ Fungsi jantung dapat diketahui dengan melakukan pemeriksaan salah satu indeks fungsi sistolik, antara lain fraksi ejeksi dan fraksi pemendekan. Fraksi ejeksi menggambarkan fungsi ventrikel kiri yang berhubungan dengan perubahan volume ventrikel kiri dengan kontraksi jantung. ${ }^{10}$

Penelitian fungsi jantung pada orang dewasa dengan KEP dan pada binatang percobaan telah banyak dilakukan, namun sayangnya penelitian pada anak hanya sedikit sedangkan anak merupakan kelompok usia dengan prevalensi KEP yang tinggi. ${ }^{8}$ Tujuan penelitian ini adalah untuk mengetahui fraksi ejeksi ventrikel kiri anak-anak dengan berbagai derajat KEP yang berkunjung ke instalasi rawat jalan dan yang dirawat di Bagian Ilmu Kesehatan Anak (BIKA) RSUP Dr. Hasan Sadikin, Bandung dengan menggunakan alat ekokardiografi.

\section{Subyek Penelitian}

Subyek penelitian adalah anak dengan berbagai derajat KEP yang berkunjung ke instalasi rawat jalan dan yang dirawat di Bagian Ilmu Kesehatan Anak RSUP Dr. Hasan Sadikin, Bandung, dengan kriteria inklusi: anak berusia 4 bulan sampai 9 tahun (wanita) dan 11 tahun (laki-laki), memenuhi kriteria KEP berdasarkan klasifikasi Waterlow dengan baku WHO-NCHS, tidak mempunyai penyakit jantung bawaan maupun didapat, tidak mengalami demam, tidak mengalami diare/muntah dengan dihidrasi berat, tidak menderita anemia berat dan orang tua / wali mengizinkan untuk mengikuti sertakan anaknya dalam penelitian setelah diberi penjelasan (informed consent).

\section{Metoda Penelitian}

Penelitian ini merupakan suatu penelitian deskriptif prospektif. Pemilihan subyek dilakukan secara sampling from consecutive admission pada anak KEP yang memenuhi kriteria inklusi. Ukuran sampel ditentukan berdasarkan biaya yaitu 30 orang. Penelitian dilakukan mulai bulan Desember 2000 sebanyak 30 sampel, di instalasi rawat jalan dan rawat inap BIKA serta diruang pemeriksaan ekokardiografi RSUP Dr. Hasan Sadikin, Bandung.

Semua subyek yang memenuhi kriteria inklusi, dicatat nama, alamat, usia dan jenis kelamin serta dilakukan pemeriksaan fisik. Pengukuran berat badan dilakukan oleh peneliti dengan subyek dalam keadaan telanjang atau dengan pakian dalam yang ringan. Bagi anak yang berusia sampai 24 bulan menggunakan timbangan bayi, sedangkan anak yang berusia $\geq 25$ bulan menggunakan timbangan berdiri Platform Balance Scale. Pengukuran tinggi badan dilakukan oleh peneliti dengan dibantu oleh seorang perawat yang sudah dilatih sebelumnya. Bayi yang berusia $\leq 24$ bulan diukur dalam posisi berbaring dengan menggunakan alat pengukur panjang bayi yang terbuat dari kayu. Sedangkan anak yang berusia $\geq 24$ bulan, tinggi badan diukur dalam posisi berdiri dengan menggunakan alat microtoire.

Status gizi ditentukan berdasarkan indeks berat badan menurut panjang / tinggi badan (BB/BT), kemudian dihitung persentasenya terhadap median dengan menggunakan baku WHO-NCHS. Khusus bagi anak KEP berat yang dirawat dicatat hasil laboratoriumnya, meliputi $\mathrm{Hb}$, kalium dan natrium serum serta kadar protein total dan albumin serum.

Selanjutnya seluruh subyek penelitian dilakukan pemeriksaan ekokardiografi oleh konsulen kardiologi BIKA-FKUP RSUP Dr. Hasan Sadikin Bandung dengan menggunakan alat ekokardiografi Sonoline S11200, merek Siemens Tahun 1989. Transduser yang digunakan adalah $5 \mathrm{MHz}$. Semua subyek penelitian diperiksa dalam posisi terlentang dan dalam keadaan tenang. Jika pasien menangis, diberikan stesolid rektal. Selanjutnya semua subyek dilakukan pemeriksaan fraksi ejeksi ventrikel kiri dengan ekokardiografi MMode pada potongan sumbu panjang parasternal, kursor diletakkan pada ujung katup mitral dengan monitor EKG. Parameter yang dinilai sbb:

Fraksi ejeksi $(\mathrm{FE})=\frac{\text { DVKI-AD-DVKI-AS }}{\text { DVKI-AD }} \times 100 \%$

DVKI-AD

Keterangan:

- DVKI-AD adalah dimensi ventrikel kiri pada saat akhir diastol

- DVKI-AS adalah dimensi ventrikel kiri pada saat akhir sistol

\section{Hasil}

Selama penelitian yang dilakukan antara bulan Desember 2000 sampai dengan Februari 2001, dari 41 anak KEP yang datang ke instalasi rawat jalan dan 
161 anak KEP yang dirawat, didapatkan 30 anak KEP yang memenuhi kriteria inklusi, masing-masing 24 anak dari instalasi rawat jalan dan 6 anak yang dirawat. Dari 30 anak KEP, didapatkan 10 (33,3\%) anak lakilaki dan $20(66,7 \%)$ anak perempuan. Usia subyek mempunyai rentang yang lebar, yaitu berkisar antara 11 bulan sampai 126 bulan (10,5 tahun) dengan median 41 bulan.

Status gizi subyek penelitian berdasarkan klasifikasi Waterlow berkisar antara $58 \%$ sampai $89,9 \%$ (Lampiran 1), rata-rata 78,9\% dengan simpang baku 7,6\%. Dari 30 subyek penelitian masing-masing terdiri dari $15(50 \%)$ anak KEP I, II (36,7\%) anak KEP II dan 4 (13,3\%) anak KEP III.

Pada penelitian ini tekanan darah semua subyek penelitian dalam batas normal sesuai usia dan jenis kelamin; tidak terdapat subyek dengan bradikardi, dan hanya satu subyek dengan takikardi (Tabel 1).

Dari ke-empat subyek penelitian dengan KEP III, hanya 2 subyek (yang dirawat) yang diketahui hasil laboratoriumnya, sedangkan 2 subyek lainnya (yang tidak dirawat) tidak diketahui hasil laboratoriumnya, karena orang tua menolak untuk dilakukan pemeriksaan darah. Keduanya memiliki kadar $\mathrm{Hb}$ yang rendah yaitu 8,4 g/dl dan 10,5 g/dl. Sedangkan kadar Hb subyek rawat inap lainnya yaitu subyek dengan Idiophatic Thrombocytopenic Purpura (ITP) dan anemia aplastik masing-masing adalah 9,3 g/dl dan 10,9 g/dl. Sedangkan 2 orang subyek dengan demam tifoid masing-masing adalah 9,3 g/dl dan 9,8 g/dl.

Kadar kalium $(\mathrm{K})$ dan natrium $(\mathrm{Na})$ serum pada subyek KEP III yang dirawat dalam batas normal; yaitu kadar K 4,3 mEq/L dan 3,5 mEq/L serta kadar $\mathrm{Na}$ $135 \mathrm{mEq} / \mathrm{L}$ dan $137 \mathrm{mEq} / \mathrm{L}$. Kadar protein total dan albumin subyek rendah, yaitu kadar protein total 3,9 $\mathrm{g} / \mathrm{dl}$ dan 5,9 g/dl, sedangkan kadar albumin 1,6 g/dl dan $2,7 \mathrm{~g} / \mathrm{dl}$.

Pada penelitian ini didapatkan bahwa sebagian besar subyek penelitian $(83,3 \%)$ mempunyai nilai fraksi ejeksi yang rendah $(<64 \%)$, hanya $16,7 \%$ mempunyai nilai fraksi ejeksi normal ( $\geq 64 \%)$. Fraksi ejeksi subyek penelitian berkisar antara $42 \%$ sampai $77 \%$ (lampiran 2), dengan rata-rata $56 \%$ dan simpang baku 7,6\%. Sebelas (73,3\%) subyek KEP I dan 10 (90,0\%) subyek

Tabel 1. Karakteristik subyek penelitian berdasarkan derajat KEP

\begin{tabular}{|c|c|c|c|}
\hline Karakteristik & $\begin{array}{c}\text { KEP I } \\
(\mathrm{n}=15) \\
\text { Median } \\
\text { (Rentang) }\end{array}$ & $\begin{array}{c}\text { KEP II } \\
(\mathrm{n}=11) \\
\text { Median } \\
\text { (Rentang) }\end{array}$ & $\begin{array}{l}\text { KEP III } \\
\quad(\mathrm{n}=4) \\
\text { Median } \\
\text { (Rentang) }\end{array}$ \\
\hline Usia (bulan) & $\begin{array}{c}60 \\
(25-126)\end{array}$ & $\begin{array}{c}29 \\
(16-111)\end{array}$ & $\begin{array}{c}33 \\
(11-43)\end{array}$ \\
\hline Berat badan (kg) & $\begin{array}{c}12,0 \\
(9,0-26,5)\end{array}$ & $\begin{array}{c}8,0 \\
(6,3-21,5)\end{array}$ & $\begin{array}{c}7,5 \\
(4,1-7,8)\end{array}$ \\
\hline Tinggi badan $(\mathrm{cm})$ & $\begin{array}{c}95,0 \\
(79,3-138,0)\end{array}$ & $\begin{array}{c}79,7 \\
(68,5-134,0)\end{array}$ & $\begin{array}{c}80,8 \\
(63,8-89,0)\end{array}$ \\
\hline \multicolumn{4}{|c|}{ Tekanan darah $(\mathrm{mmHg})$} \\
\hline - Sistolik & $\begin{array}{c}80 \\
(80-110)\end{array}$ & $\begin{array}{c}85 \\
(80-115)\end{array}$ & $\begin{array}{c}95 \\
(80-105)\end{array}$ \\
\hline - Diastolik & $\begin{array}{c}55 \\
(50-80)\end{array}$ & $\begin{array}{c}60 \\
(50-80)\end{array}$ & $\begin{array}{c}57,5 \\
(40-60)\end{array}$ \\
\hline Nadi (x / menit) & $\begin{array}{c}73 \\
(72-136)\end{array}$ & $\begin{array}{c}106 \\
(92-128)\end{array}$ & $\begin{array}{c}111 \\
(92-116)\end{array}$ \\
\hline Respirasi (x / menit) & $\begin{array}{c}31 \\
(22-36)\end{array}$ & $\begin{array}{c}27 \\
(22-36)\end{array}$ & $\begin{array}{c}28,5 \\
(28-31)\end{array}$ \\
\hline Suhu $\left({ }^{0} \mathrm{C}\right)$ & $\begin{array}{c}36,4 \\
(36,0-37,1)\end{array}$ & $\begin{array}{c}36,4 \\
(36,2-37,0)\end{array}$ & $\begin{array}{c}36,7 \\
(36,5-36,9)\end{array}$ \\
\hline
\end{tabular}


Sari Pediatri, Vol. 3, No. 2, September 2001

KEP II mempunyai nilai fraksi ejeksi yang rendah dan semua subyek dengan KEP III mempunyai nilai fraksi ejeksi yang rendah. Nilai fraksi ejeksi berdasarkan cut

Tabel 2. Nilai fraksi ejeksi menurun dan normal pada KEP I,II dan III

\begin{tabular}{lcccc}
\hline Derajat KEP & \multicolumn{4}{c}{ Nilai Fraksi Ejeksi } \\
\cline { 2 - 5 } & \multicolumn{2}{c}{ Menurun $(<64 \%)$} & Normal $(\geq 64 \%)$ \\
\cline { 2 - 5 } & $\mathrm{n}$ & $\%$ & $\mathrm{n}$ & $\%$ \\
\hline KEP I & 11 & 73,3 & 4 & 26,7 \\
KEP II & 10 & 90,9 & 1 & 9,1 \\
KEP III & 4 & 100,0 & - & - \\
\hline
\end{tabular}

Lampiran 1. Status gizi subyek penelitian

\begin{tabular}{lccc}
\hline No & No Urut & BB / TB (\%) & KEP \\
\hline 1 & 7 & 89,9 & I \\
2 & 27 & 88,9 & I \\
3 & 26 & 88,8 & I \\
4 & 8 & 87,0 & I \\
5 & 14 & 86,0 & I \\
6 & 13 & 85,9 & I \\
7 & 5 & 85,5 & I \\
8 & 3 & 83,6 & I \\
9 & 20 & 83,6 & I \\
10 & 21 & 83,0 & I \\
11 & 28 & 82,5 & I \\
12 & 1 & 81,6 & I \\
13 & 30 & 81,5 & I \\
14 & 19 & 81,0 & I \\
15 & 4 & 80,0 & I \\
16 & 17 & 79,9 & II \\
17 & 11 & 79,8 & II \\
18 & 22 & 78,3 & II \\
19 & 6 & 77,7 & II \\
20 & 18 & 77,5 & II \\
21 & 9 & 76,6 & II \\
22 & 15 & 76,4 & II \\
23 & 16 & 75,4 & II \\
24 & 2 & 73,0 & II \\
25 & 23 & 73,0 & II \\
26 & 29 & 72,1 & II \\
27 & 24 & $70,2($ edema) & III \\
28 & 12 & 69,6 & III \\
29 & 10 & 61,2 & III \\
30 & 25 & 58,0 & III \\
\hline & & &
\end{tabular}

off point harga normal (64\%) tampak pada Tabel 2, sedangkan nilai fraksi ejeksi subyek penelitian berdasarkan status gizi tampak pada Tabel 3.

Tabel 3. Nilai fraksi ejeksi berdasarkan derajat KEP

\begin{tabular}{lllll}
\hline Derajat KEP & \multicolumn{4}{c}{ Nilai Fraksi Ejeksi (\%) } \\
\cline { 2 - 5 } & $\mathrm{n}$ & Rata-rata & SB* $^{*}$ & Rentang \\
\hline KEP I & 15 & 59,1 & 6,4 & $50-69$ \\
KEP II & 11 & 55,2 & 7,5 & $50-77$ \\
KEP III & 4 & 46,2 & 2,9 & $42-48$ \\
\hline
\end{tabular}

${ }^{*} \mathrm{SB}=$ simpang baku

Lampiran 2. Nilai fraksi ejeksi berdasarkan status gizi

\begin{tabular}{|c|c|c|c|c|}
\hline No & No Urut & BB / BT (\%) & KEP & $\begin{array}{c}\text { Nilai Fraksi } \\
\text { Ejeksi (\%) }\end{array}$ \\
\hline 1 & 7 & 89,9 & I & 69 \\
\hline 2 & 27 & 88,9 & I & 61 \\
\hline 3 & 26 & 88,8 & I & 67 \\
\hline 4 & 8 & 87,0 & I & 50 \\
\hline 5 & 14 & 86,0 & I & 59 \\
\hline 6 & 13 & 85,9 & I & 56 \\
\hline 7 & 5 & 85,5 & I & 51 \\
\hline 8 & 3 & 83,6 & I & 53 \\
\hline 9 & 20 & 83,6 & I & 69 \\
\hline 10 & 21 & 83,0 & I & 62 \\
\hline 11 & 28 & 82,5 & I & 64 \\
\hline 12 & 1 & 81,6 & I & 50 \\
\hline 13 & 30 & 81,5 & I & 59 \\
\hline 14 & 19 & 81,0 & I & 58 \\
\hline 15 & 4 & 80,0 & $\mathrm{I}$ & 59 \\
\hline 16 & 17 & 79,9 & II & 52 \\
\hline 17 & 11 & 79,8 & II & 53 \\
\hline 18 & 22 & 78,3 & II & 57 \\
\hline 19 & 6 & 77,7 & II & 77 \\
\hline 20 & 18 & 77,5 & II & 51 \\
\hline 21 & 9 & 76,6 & II & 50 \\
\hline 22 & 15 & 76,4 & II & 53 \\
\hline 23 & 16 & 75,4 & II & 53 \\
\hline 24 & 2 & 73,0 & II & 53 \\
\hline 25 & 23 & 73,0 & II & 52 \\
\hline 26 & 29 & 72,1 & II & 56 \\
\hline 27 & 24 & 70,2 & III & 42 \\
\hline 28 & 12 & 69,6 & III & 48 \\
\hline 29 & 10 & 61,2 & III & 47 \\
\hline 30 & 25 & 58,0 & III & 48 \\
\hline
\end{tabular}




\section{Pembicaraan}

Penelitian ini berbeda dengan penelitian-penelitian sebelumnya yaitu (1) subyek penelitian tidak terbatas pada balita, berkisar antara 11 sampai 126 bulan (10,5 tahun), mengingat nilai fraksi ejeksi tidak tergantung usia, ${ }^{11}$ (2) status nutrisi ditentukan berdasarkan klasifikasi Waterlow dengan baku WHO-NCHS (berat badan menurut tinggi badan) yang dapat digunakan sampai tinggi maksimal $137 \mathrm{~cm}$ bagi anak wanita yang berusia 9 tahun dan anak laki-laki yang berusia 11 tahun. ${ }^{12}$ Pada penelitian ini tinggi badan maksimal subyek anak wanita $134 \mathrm{~cm}$ dan anak laki-laki 138 $\mathrm{cm}$. Pada penelitian sebelumnya Phornphatkul $\mathrm{dkk}^{9}$ menggunakan klasifikasi yang sama tetapi hanya meneliti subyek dengan KEP III, sedangkan Singh dkk 5 meneliti anak dengan berbagai derajat KEP berdasarkan klasifikasi Indian Academy of Paediatrics, (3) sebagian besar subyek penelitian merupakan malnutrisi sekunder terhadap penyakit yang mendasarinya, sedangkan para peneliti sebelumnya Singh $\mathrm{dkk}^{5}$ dan Kothari $\mathrm{dkk}^{8}$ tidak mengikutsertakan subyek dengan malnutrisi sekunder.

Pada penelitian ini tidak didapatkan subyek dengan hipotensi, tekanan darah rata-rata anak KEP yang datang ke RSUP Dr. Hasan Sadikin Bandung dalam batas normal, sama halnya dengan hasil penelitian Singh $\mathrm{dkk}^{5}$, sedangkan Kothari $\mathrm{dkk}^{8}$ mendapatkan tekanan darah sistolik pada anak KEP III menurun secara bermakna bila dibandingkan dengan kontrol. Nadi subyek penelitian berkisar antara 72-136 x/menit, hanya satu subyek yang mengalami takikardi. Hasil ini berbeda dengan penelitian Kothari $\mathrm{dkk}^{8}$ yang mendapatkan nadi penderita KEP III sedikit meningkat dibandingkan kontrol meskipun kenaikan ini tidak bermakna. Sedangkan hasil Singh $\mathrm{dkk}^{5}$ menunjukkan peningkatan nadi yang sangat bermakna dengan bertambah beratnya derajat KEP. Pada KEP, isi sekuncup berkurang; untuk mempertahankan curah jantung agar dapat memenuhi kebutuhan metabolisme; tubuh akan melakukan kompensasi untuk meningkatkan curah jantung melalui peningkatan frekuensi jantung. ${ }^{5,13}$

Pada penelitian ini didapatkan bahwa sebagian besar subyek penelitian mempunyai nilai fraksi ejeksi yang rendah, khususnya subyek dengan status gizi KEP III. Nilai fraksi ejeksi yang rendah pada sebagian besar subyek penelitian mungkin disebabkan oleh (1) kontraktilitas otot yang buruk akibat atrofi otot jantung dan (2) kemungkinan sudah terjadi defisiensi mikronutrien pada sebagian subyek penelitian. Defisiensi mikronutrien dalam hal ini trace element dapat menurunkan kontraktilitas otot jantung melalui gangguan fungsi sel otot jantung. ${ }^{14}$ Sayangnya seluruh subyek penelitian tidak dilakukan pemeriksaan mikronutrien.

Subyek dengan kwashiokor mempunyai nilai fraksi ejeksi yang sangat rendah. Hal ini selain disebabkan oleh kontraktilitas otot yang buruk akibat atrofi otot jantung dan kemungkinan sudah terjadi defisiensi mikronutrien, juga bisa disebabkan oleh hipoalbuminemia yang cukup berat $(1,6 \mathrm{gr} / \mathrm{dl})$. Hipoalbuminemia yang berat akan menyebabkan ekstravasasi cairan dari intra ke ekstravaskular, sehingga volume intravaskular akan berkurang yang selanjutnya akan mengurangi aliran darah vena (preload). Hal ini sesuai dengan hasil penelitian Phornphatkul $\mathrm{dkk}^{9}$ yang memperlihatkan bahwa fungsi ventrikel kiri dalam hal ini curah jantung pada kwashiorkor lebih terganggu dibandingkan dengan marasmus.

Nilai fraksi ejeksi subyek dengan KEP III pada penelitian ini berbeda dengan hasil penelitian Kothari $\mathrm{dkk}^{8}$, yang menyimpulkan bahwa tidak terdapat gangguan fungsi ventrikel yang bermakna pada pasien dengan KEP berat (marasmus dan marasmikkwashiorkor). Pada penelitian tersebut, subyek dengan injeksi dan KEP sekunder merupakan kriteria eksklusi dan tidak diikut sertakan dalam penelitian; sedangkan pada penelitian ini, sebagian besar subyek mengalami infeksi dan mungkin KEP sekunder, sehingga hasil kedua penelitian tersebut tidak dapat dibandingkan.

Demikian pula halnya dengan penelitian Singh $\mathrm{dkk}^{5}$, nilai fraksi ejeksi pada penelitian ini tidak dapat dibandingkan; disamping klasifikasi status gizi subyek penelitian yang berbeda, pada penelitian Singh $\mathrm{dkk}^{5}$ adanya penyakit kronis dan anemia merupakan kriteria eksklusi dan tidak diikut sertakan dalam penelitian, sedangkan pada penelitian ini penyakit kronis dan anemia ringan merupakan kriteria inklusi (Lampiran 3).

Pada penelitian ini tidak dianalisa mengenai perbedaan fraksi ejeksi dari masing-masing derajat KEP, mengingat penelitian ini adalah penelitian deskriptif. Untuk selanjutnya perbedaan nilai fraksi ejeksi untuk berbagai derajat KEP akan dianalisis lebih lanjut. 
Sari Pediatri, Vol. 3, No. 2, September 2001

Lampiran 3. Nilai fraksi ejeksi berdasarkan diagnosis

\begin{tabular}{lccl}
\hline No & No Urut & Fraksi Ejeksi (\%) & \\
\hline 1 & 7 & 89,9 & Marasmus \\
2 & 27 & 88,9 & Marasmus + CP + Delayed development \\
3 & 26 & 88,8 & Marasmus + CP + Delayed development \\
4 & 8 & 87,0 & Kwashiokor + Mikrosefal + Anemia \\
5 & 14 & 86,0 & KEP II + Tonsilofaringtis \\
6 & 13 & 85,9 & KEP II + TB Paru dalam terapi (3bl) \\
7 & 5 & 85,5 & KEP II + TB Paru dalam terapi (1bl) \\
8 & 3 & 83,6 & KEP II \\
9 & 20 & 83,6 & KEP II \\
10 & 21 & 83,0 & KEP II \\
11 & 28 & 82,5 & KEP II + Tonsilofaringtis \\
12 & 1 & 81,6 & KEP II + ITP \\
13 & 30 & 81,5 & KEP II + Anemia aplastik \\
14 & 19 & 81,0 & KEP II + Tansilofaringtis + Piodermia \\
15 & 4 & 80,0 & KEP II + Tansilofaringtis \\
16 & 17 & 79,9 & KEP II + Demam tifoid (perbaikan) + TB paru \\
17 & 11 & 79,8 & KEP I + Suspek TB paru \\
18 & 22 & 78,3 & KEP I \\
19 & 6 & 77,7 & KEP I + Diare akut non disentri tanpa dehidrasi \\
20 & 18 & 77,5 & KEP I + TB paru dalam terapi (6bl) \\
21 & 9 & 76,6 & KEP I + Diare akut non disentri tanpa dehidrasi \\
22 & 15 & 76,4 & KEP I \\
23 & 16 & 75,4 & KEP I \\
24 & 2 & 73,0 & KEP I + TB paru dalam terapi (1bl) \\
25 & 23 & 73,0 & KEP I + TB paru dalam terapi (5bl) \\
26 & 29 & 72,1 & KEP I \\
27 & 24 & 70,2 & KEP I \\
28 & 12 & 69,6 & KEP I + Tonsilofaringtis \\
29 & 10 & 61,2 & KEP I + Demam tifoid (perbaikan) \\
30 & 25 & 58,0 & KEP I \\
\hline & & &
\end{tabular}

Sebagai kesimpulan yaitu (1) sebagian besar $(83,3 \%)$ anak KEP di RSUP Dr. Hasan Sadikin Bandung mempunyai nilai fraksi ejeksi yang normal dan (2) pada sebagian besar (73,3\%) anak KEP I sudah didapatkan nilai fraksi ejeksi yang menurun, dengan nilai fraksi ejeksi rata-rata 59,1\%(SB 6,4). Sedangkan anak KEP II nilai fraksi ejeksi yang rendah didapatkan pada 90,9\% anak, dengan nilai fraksi ejeksi rata-rata $55,2 \%(S B$ 7,5). Pada anak KEP III, nilai fraksi seluruhnya rendah dengan nilai fraksi ejeksi rata-rata $46,2 \%($ SB 2,9).

Berdasarkan penelitian ini, hendaknya kita harus lebih berhati-hati dalam penatalaksanaan anak dengan KEP, karena gangguan fungsi jantung sudah terjadi pada anak KEP I dan II. Untuk mendapatkan gambaran yang lebih luas mengenai nilai fraksi ejeksi pada anak KEP di Indonesia sebagai salah satu upaya untuk melengkapi data dasar mengenai keterlibatan kardiovaskular pada anak KEP, perlu dilakukan penelitian lebih lanjut dengan jumlah sampel yang lebih besar, pemeriksaan laboratorium dan parameter ekokardiografi yang lebih lengkap. Disamping itu perlu dilakukan penelitian lebih lanjut mengenai nilai fraksi ejeksi anak dengan gizi baik di Indonesia, mengingat belum pernah dilakukan penelitian mengenai hal ini dan tidak menutup kemungkinan bahwa nilai fraksi ejeksi anak dengan gizi baikpun berbeda dengan nilai normal di luar negeri. 


\section{Daftar Pustaka}

1. Curran JS, Barness LA. Malnutrition. Dalam: Behrman RE, Klieman RM, Jenson HB, penyunting. Nelson Textbook of Pediatrics; edisi ke-16, Philadelphia: WB Saunders, 2000. h. 169-72.

2. Kurniawan A, Latief D. Chilhood malnitrition in Indonesia Its Current Situation. Dipresentasikan pada the joint Symposium Between Department of Nutrition \& Department of Pediatrics Faculty of Medicine, Sebelas Maret University and The Centre for Human Nutrition, University of Sheffield, UK: Childhood malnutrition: Its Consequences and Management, Surakarta, February 19, 2001.

3. Talner NS. Cardiac changes in the malnourished child. Dalam: Suskind RM, Suskind LL, penyunting. The Malnourished Child. New York: Nestec Ltd, 1990; 19. h. 229-41.

4. Waterlow JC. Effects of PEM on structure and functions of organs. Dalam: Protein energy malnutrition. London: Edward Arnold, 1992.h. 55-81.

5. Singh GR, Malathi KE, Kasliwal RR, Ommar A, Padmavati S, Ramji S. An evaluation of cardiac function in malnourished children by non-invasive metheds. Indian Pediatric 1989; 26.h. 875-81.

6. Hansen JDL, Pettifor JM. Protein energy malnutrition (PEM). Dalam: Mc Laren DS, Burman D, Belton NR, William AF, penyunting. Textbook of Pediatric Nutrition; edisi ke-3. Edinburgh: Churchill Livingstone, 1991. h. 357-90.
7. Friedman WF. Acquired heart disease in infancy and chilhood. Dalam: Braunwald E, penyunting. Heart Disease A Textbook of Cardiovaskular Medicine; edisi ke-4. Philadelphia: WB Saunders, 1992.h. 992-1006.

8. Kothari SS, Patel TM, Shetalwad AN, Patel TK. Left ventricular mass and function in children with severe protein energy malnutrition. Int. J Cardiol 1992; 35: $19-25$.

9. Phornphatkul C, Pongprot Y, Suskind R, George V, Fuchs G. Cardiac function in malnourished children. Clin Pediatric (Philadelphia) 1994; 33: 147-54.

10. Park MK. Noninvasive technigues. Dalam: Pediatric Cardialogy for Practitioners; edisi ke-3. St. Louis; Mosby, 1996.h. 67-82.

11. Henry WL, Gardin JM, Ware JH. Echocardiographic measurements in normal sebject from infancy to old age. Circulation 1980; 62:1954-61.

12. Gorstein J dkk. Issues in the assessment of nutritional status using anthropomentry. Bull WHO 1994; 72 (2): 273-83.

13. Cohen MI dan Clark BJ. Rapid heart rate. Dalam: Schwartz MW, penyunting. Clinical Handbook of Pediatrics; edisi ke-2, Baltimore: Williams \& Wilkins Company, 1999.h. 557-9.

14. Emmanouilides GC. Cardiomyophaty. Dalam: Emmanoulides GC, Allen HD, Riemenschneider TA, Gutgesell HP, penyunting. Clinical Synopsis of Moss and Adam's Heart Disease in Infants, Children, and Adolescents. Baltimore: Williams \& Wilkins, 1998.h. 526-50. 